\section{ON THE TREATMENT OF SMALL-POX.}

By AQUILLA SMITH, M.D.,

King's Professor of Materia Medica in Trinity College, Dublin, etc.

IN the Life of Sydenham, prefixed to Dr. Latham's translation of his works published by the Sydenham Society, a very candid and impartial account is given of the "cooling treatment of the small-pox" by the great physician of the seventeenth century, of whom he says : "The change that Sydenham introduced was not the change from one extreme to (comparatively speaking) another; but rather a media via between two contrasting methods-the method of promoting the eruption by blankets and brandy, and the method of replacing it by blood-letting and purging. Sydenham's method was really, in the eyes of its author, a golden mean between the cordial system and the evacuant system." (Life, p. lxviii.)

In the letter of Dr. J. Crane, of Dorchester, reprinted by Dr. Latham from the Gentleman's Magazine of July I790, the writer alludes to Sydenham's letter addressed to Dr. Cole, of Worcester, in 1682, and says : "Now, I shall take leave to go further back, and affirm that even Dr. Sydenham was not the first who pointed out the cool regimen in the small-pox, but that the mode of treating the disease was known to, and practised by, an ancestor of mine, born fifty-three years before Sydenham, of whom some mention is made in the Life of Lord Clarendon. This person, by name John Crane, was my great-great-great-grandfather, and practised at Cambridge, where he died in 1652 , aged 81 years." "To preserve the claim of my reverend forefather to the merit of being the first who systematically pursued the cool regimen in the small-pox, I request your insertion of this in your valuable repository; for, though tradition has handed down the fact, it will otherwise insensibly fall into oblivion, as there are no printed documents extant to prevent its sharing that common fate." (Life, pp. lxx, lxxi.)

The object of this communication is to shew that, "though tradition has handed down the fact", there is printed documentary evidence extant, from which it appears that some of the most important principles "of the cool regimen in small-pox" were "pursued" as far back as the year 1584; at which period John Crane, of Cambridge, was only 27 years old.

The book from which I am about to quote was written by Scévole de Sainte-Marthe (Latinè, Sammarthanus), in $15^{4}$, as appears from the date of his letter on presenting his Latin poem, Pedotrophia, to Henry III of France. The full title of the poem is, Pcedotrophia, seu de Puerorum Nutritione, libri iii. The third book treats of those diseases, eighteen in number, to which children are subject soon after their birth; but, as it would occupy too much space to give an analysis of this remarkable poem, written in excellent Latin, by a distinguished Frenchman, who was not a physician, I shall quote only certain passages relating to the treatment of small-pox.

Sainte-Marthe describes two forms of the disease (Editio 1698, page rog):-

"Nam geminæ morbi (quanquam discrimine parvo)

Sunt species."

$\mathrm{He}$ recommends frequent draughts of cold water until vomiting is excited.

"Continuò incensos avertere profuit æstus

Porrectis gelidæ rivis, quæ frigeret intus

Viscera, sed primo vix id contingat ab haustu.

Ergo redintegrant lymphas, vomituque frequenti

Efficiunt, ne fortè novo non usque liquori

Sit locus, et potu repetito incendia sedant."

He recommends also a regulated diet, along with purgation by manna or cassia, which medicines, in the case of a young child, may be taken by its nurse.

"Additur et victûs ratio: nam dulcia vitant,

Fructùsque; immodico quicunque humore putrescunt,

Tum Syrio rore, aut casia medicata propinant

Pocula, quæ invalidi nutrix vice sumat alumni." (P. II3.)

He was aware of the great danger of attempting to drive out the disease.

"Tantùm hoc moneo ne publicus error

Te teneat, qui non fallit muliebria tantùm

Pectora, verum ipsos etiam plerunque medentes;

Omnia dum faciunt ut quantuncunque veneni

Intus inest penitus se in apertas proferat auras.

Quippe adeo plena ingentis res ifla pericli,
Erumpat ne vi nimiâ, nec in extera tantùm

Sæviat effusæ largissima copia pestis :

Verùm ipsas etiam numeroso vulnere fauces

Occupit, obsessæque animæ spiracula claudat." (P. I13.)

If he apprehended retrocession of the eruption, he would dare to bleed.

"Ne loca jam erumpens revocetur ad intima virus,

Ausim equidem ægroti salientem incidere venam,

Humorisque aliò nonnullam avertere partem." (P. I I4.)

In order to expel the morbid humours by sweating, he recommends : "Natura juvanda est

Auxiliis, terra alma sinu quæ divite promet

Plurima, teque areò ante omnes quæ nomen ab ulmo*

Herba capis, veterum priscis ignota parentum

Temporibus, nostri decus et nova gloria sæcli.

Insita quippe tuo vis admiranda liquori

Sudorem elicere immundum, fædamque soluto

Corpore contagem aërias educere in auras."

To promote the exfoliation of the crusts, which he compares to the falling of leaves in autumn, he recommends fomentations of roses and myrtle,

$$
\text { " Atque oleo cerusæ }+ \text { illeveris omnes, }
$$

Ilicet has toto de corpore sentiat infans

Effluere, et toto sparsas horrescere lecto."

(P. 117.$)$

I do not know of any application so effectual in relieving the itching of the face, which is so distressing to the patient in small-pox, as a mixture of one part of solution of subacetate of lead with seven parts of olive or almond oil, applied by means of a feather or soft brush.

The Padotrophia passed through ten editions during the life of the author, and many subsequent editions; it was translated into French, both in prose and yerse, and there are two translations into English verse ; yet, with all this publicity, I do not find in Moore's History of the Sinall-Pox any mention of Sainte-Marthe, nor is his name to be found in the bibliography appended to the article "Small-pox", in the Cyclopadia of Practical Medicine or in Copland's Dictionary of Mediline.

\section{VALERIAN IN THE TREATMENT OF PERTUSSIS AND LARYNGISMUS STRIDULUS.}

\author{
By GEORGE HILL, M.D., Hooton, Chester.
}

IN recommending a remedy in the treatment of hooping-cough, one almost feels as if an apology were due-so numerous are the medicines which have been prescribed, and so unsuccessful in their application. But I have recently had an excellent opportunity of testing the effects of various medicines in this obscure complaint, during an epidemic which has prevailed in this neighbourhood for several months.

The chief indication to be fulfilled in the treatment of uncomplicated hooping-cough is to mitigate the severity of the symptoms due to the nervous system - to alleviate the spasm from which the disease has its name. For this object, I know of no medicine so efficacious as valerian. It were needless to cite examples illustrative of its beneficial effects : suffice it to say that, in almost every case in which I prescribed it, there was a marked diminution within eight-and-forty hours, not only in the frequency of the paroxysms, but in the severity of the spasmodic element. I have likewise used nitric acid with advantage; but it seems more suitable during the decline of the disease, when its good effects are to be ascribed to its general tonic properties, rather than to any specific action. The administration of prussic acid, alum, and cochineal has been attended with no success. I was led to employ valerian in this disease by the success with which $I$ have recently used it in laryngismus stridulus- a complaint in a certain degree analogous to hooping-cough, in so far as the excito-motory system is involved. I relate but one case. The patient was a child four months old, in whom stridulous breathing had continued for some weeks. I was called when general convulsions supervened, and found that the disease was due to stomachal and intestinal irritation, arising from improper diet. The regulation of this, however, was not alone sufficient to cause any abatement of the symptoms; but, after the administration of valerian, the carpo-pedal contractions disappeared, stridulous breathing recurred but once, and the general irritation of the nervous system was allayed. It is an objection, that the drug is nauseous; but, by combining it with some aromatic, this may be easily overcome.

* Meadowsweet, or Spiræa ulmaria, which is in the list of Materia Medica and Preparations prefixed to the translation of Sydenham's works, vol. i, page c.

" "Cerusa, i.e., plumbi erugo, Bleyweiss" (white-lead), see Rulandus, Lexicon Alchemia, 4to, I6:2. 